Mеталлофиз. новейшие технол. / Metallofiz. Noveishie Tekhnol. () 2017 ИМФ (Институт металлофизики 2017 , т. 39, № 11, сc. 1547-1556 / DOI: 10.15407/mfint.39.11.1547 им. Г. В. Курдюмова НАН Украины) Оттиски доступны непосредственно от издателя

Фотокопирование разрешено только

Напечатано в Украине.

в соответствии с лицензией

PACS numbers: 61.05.cp, 64.75.St, 68.35.bd, 68.35.Dv, 68.37.Hk, 68.37.Lp, 81.15.Pq

\title{
Structural and Microstructural Analysis of Zn-Mo Alloy Layers Electrodeposited from Aqueous Citrate Solution
}

\author{
Z. Świątek, H. Kazimierczak, P. Ozga, O. Bonchyk*, and H. Savytskyy* \\ Institute of Metallurgy and Materials Science, \\ Polish Academy of Sciences, \\ 25 Reymonta, \\ 30-059 Krakow, Poland \\ "Ya.S. Pidstryhach Institute for Applied Problems of Mechanics and Mathematics, \\ N.A.S. of Ukraine, \\ 3-b Naukova Str., \\ 79060 Lviv, Ukraine
}

The paper presents results of the phase-composition and microstructure studies of the $\mathrm{Zn}-$ Mo alloy electrodeposited layers. The $\mathrm{Zn}-\mathrm{Mo}$ coatings are electrodeposited from sulphate-citrate electrolytes on a steel substrate. As revealed in SEM, TEM and x-ray diffraction studies, the coatings consist of the phase crystallized in hexagonal system and contain less than $0.8 \%$ wt. Mo built-in the Zn-crystal structure. The presence of Mo atoms causes fragmentation of the crystallites.

Key words: electrodeposition, corrosion, zinc-based alloys, phase composition, $\mathrm{x}$-ray diffraction.

У статті представлено результати досліджень фазового складу та мікроструктури електролітично осаджених шарів стопів Zn-Mo. Покриття ZnМо було одержано на сталевому підложжі електролітичним осадженням з сульфат-цитратних електролітів. Дослідження методами CEM, TEM і peнтгенівської дифракції показали, що покриття складаються з кристалізованої в гексагональній системі фази та містять менше 0,8\% мас. Мо, вбудованого у кристалічну гратницю цинку. Наявність атомів Мо викликає

Corresponding author: Zbigniew Świątek

E-mail: z.swiatek@imim.pl

Please cite this article as: Z. Świątek, H. Kazimierczak, P. Ozga, O. Bonchyk, and H. Savytskyy, Structural and Microstructural Analysis of Zn-Mo Alloy Layers Electrodeposited from Aqueous Citrate Solution, Metallofiz. Noveishie Tekhnol., 39, No. 11: 1547-1556 (2017), DOI: 10.15407/mfint.39.11.1547. 
фрагментацію кристалітів.

Ключові слова: електролітичне осадження, корозія, стопи на основі цинку, фазовий склад, рентгенівська дифракція.

В статье представлены результаты исследований фазового состава и микроструктуры, электролитически осаждённых слоёв сплавов $\mathrm{Zn}-\mathrm{Mo}$. Покрытия Zn-Mо были получены на стальной подложке электролитическим осаждением из сульфат-цитратных электролитов. Исследования методами СЭМ, ТЕМ и рентгеновской дифракции показали, что покрытия состоят из кристаллизованной в гексагональной системе фазы и содержат менее $0,8 \%$ масс. Мо, встроенного в кристаллическую решётку цинка. Наличие атомов Мо вызывает фрагментацию кристаллитов.

Ключевые слова: электролитическое осаждение, коррозия, сплавы на основе цинка, фазовый состав, рентгеновская дифракция.

(Received October 11, 2017)

\section{INTRODUCTION}

Protective layers of zinc and zinc-based materials belong to the most cost-effective anticorrosion coatings and thus are widely used in the automotive and aircraft industries, fuel industry, armaments industry, and many other branches of economics [1,2].

For plenty of years, intensive search has been conducted for thinner corrosion-resistant zinc-based coatings, which could also replace protective layers containing cadmium [3]. Among the most promising materials, there are electrolytic alloys of zinc with molybdenum. They are especially interesting as replacement materials for cadmium layers and for zinc coatings with $\mathrm{Cr}$ (VI)-based conversion layers.

The purpose of this work is to carry out the microstructural and structural characterizations of the zinc-molybdenum alloy layers obtained by an electrolytic deposition from sulphate-citrate electrolytes.

\section{EXPERIMENT DETAILS}

\subsection{Electrodeposition Process and Chemical Composition}

The $\mathrm{Zn}-$ Mo coatings were electrodeposited from sulphate-citrate electrolytes on a steel substrate. The chemical composition of the used electrolytes and details of electrodeposition process are presented in [4] (see also Table 1).

The chemical composition and mass of the deposits are determined by EDS (energy dispersive $\mathrm{x}$-ray spectroscopy) and WDXRF (wavelength dispersive $\mathrm{x}$-ray fluorescence) analyses. 


\subsection{Phase and Microstructure Effects' Analysis}

The x-ray powder diffraction data were collected on the Philips diffractometer type X'Pert in the Bragg-Brentano geometry. $\mathrm{Cu} K_{\alpha^{-}}$ radiation ( $\lambda=0.154184 \mathrm{~nm}$ wavelength) diffracted by sample was selected by a graphite monochromator. The scanning voltage of the x-ray tube was $40 \mathrm{kV}$, the current was $25 \mathrm{~mA}$, the exposure time was $1 \mathrm{~s}$ and the measured angle, $2 \theta$, was from $10^{\circ}$ to $100^{\circ}$. The scanning step was $0.02^{\circ}$. The x-ray diffraction data were processed by the FullProf Suite program (version September-2012) [5].

Structural refinement was performed using the whole-pattern decomposition (Profile Matching) procedure (also known as LeBail fitting [6]), as implemented in the FullProf program [7]. The lattice parameters were precisely determined by Dicvol04 program [8]. The peak profiles were modelled using the Thompson-Cox-Hastings modified pseudo-Voigt (TCH-pV) function [9] to evaluate isotropic size and strain effects. The background was modelled by linear interpolation between consecutive break points of the pattern. Symmetrized cubic harmonics were used to model size anisotropy and quartic forms to describe strain anisotropy effects [10], according to the procedure described in the FullProf software manual. The instrumental contribution was evaluated by refining the trend of the peak parameters with $2 \theta$ on a suitable reference pattern.

The morphology of the resulting coatings was studied by scanning electron microscopy (SEM). The SEM analysis was performed using a JEOL JSM-7500F Field Emission Scanning Electron microscope equipped with INCA PentaFETx3 Oxford Instruments EDS system.

The microstructure of obtained layers was investigated using FEI TECNAI SuperTWIN FEG (200 kV) microscope. Thin foils for TEM were cut out using FEI Quanta 200 dual beam focused ion beam (FIB).

TABLE 1. Chemical composition of electrolytic bath, values of selected operating parameters and Mo content in deposited layers $\left(\mathrm{Cit}=\mathrm{C}_{6} \mathrm{H}_{4} \mathrm{O}_{7}\right)$.

\begin{tabular}{|c|c|c|c|c|c|c|c|}
\hline Sample & $\begin{array}{c}\mathrm{Cit}, \\
\mathrm{mol} / \mathrm{dm}^{3}\end{array}$ & $\begin{array}{c}\mathrm{ZnSO}_{4}, \\
\mathrm{~mol} / \mathrm{dm}^{3}\end{array}$ & $\begin{array}{l}\mathrm{Na}_{2} \mathrm{MoO}_{4}, \\
\mathrm{~mol} / \mathrm{dm}^{3}\end{array}$ & $\begin{array}{l}Q, \\
{ }^{\circ} \mathrm{C}\end{array}$ & $\begin{array}{l}E, \\
\text { V }\end{array}$ & $\begin{array}{l}\omega, \\
\text { rps }\end{array}$ & $\begin{array}{l}\text { Mo, } \\
\% \text { wt. }\end{array}$ \\
\hline 1 & 0.25 & 0.16 & 0 & 100 & 2.8 & 39.77 & 0 \\
\hline 2 & 0.25 & 0.16 & 0.24 & 350 & -2 & 15.7 & 0.5 \\
\hline 3 & 0.65 & 0.16 & 0.24 & 150 & -1.4 & 15.7 & 0.8 \\
\hline 4 & 0.25 & 0.16 & 0.24 & 50 & -1.3 & 15.7 & 3.6 \\
\hline 5 & 0.25 & 0.16 & 0.24 & 100 & -1.3 & 15.7 & 6.7 \\
\hline 6 & 0.45 & 0.16 & 0.24 & 350 & -1.3 & 15.7 & 12 \\
\hline 7 & 0.25 & 0.16 & 0.24 & 50 & -1.3 & 1.05 & 24.8 \\
\hline
\end{tabular}




\section{RESULTS AND DISCUSSION. STRUCTURE AND MICROSTRUCTURE OF DEPOSITED ALLOYS}

The surface morphology of Zn-Mo coatings definitely differs according to the content of molybdenum in them. Figure 1 presents SEM images of selected coatings with 0.8 (Fig. 1, $a$ ) and 3.6\% wt. Mo (Fig. 1, $b$ ). For the low content of molybdenum, a compact fine cellular-platelet structure can be observed. The morphology of coatings with $3.6 \%$ wt. molybdenum content is characterized by flake-like particles protruding from the compact cellular-platelet layer. The layers with high molybdenum content additionally consist of agglomerates of short needles and elongated platelets. Even these simple observations using SEM technique provide information about fine-crystalline nature of the layers.

From the analysis of the x-ray diffraction patterns of Zn-Mo layers, it is evident that practically single-phase deposits with the same type of crystal lattice (of hexagonal close-packed one) were obtained (Fig. 2 ). The exception is the sample No. 2 in which additionally $\mathrm{ZnO}$ was identified. In the crystal structure of these (Zn, Mo) phases, the Mo atoms are 'substituted' by the $\mathrm{Zn}$ atoms from the crystal lattice of zinc.

The replacement of $\mathrm{Zn}$ by Mo in the hexagonal lattice cell leads to a fast decrease in the cell parameter $c$ and a slight increase in $a$ (Fig. 2, $b$ ). Moreover, the unit cell parameters do not much change when the content of Mo in $\mathrm{Zn}-$ Mo layers increases up to about $24.8 \%$ wt. Observed change in the unit cell parameters' value, when there is such a large difference in the atomic radii of the two components $(1.90 \AA \mathrm{vs}$. $1.42 \AA$ ), leads to the conclusion that the maximum content of molyb-
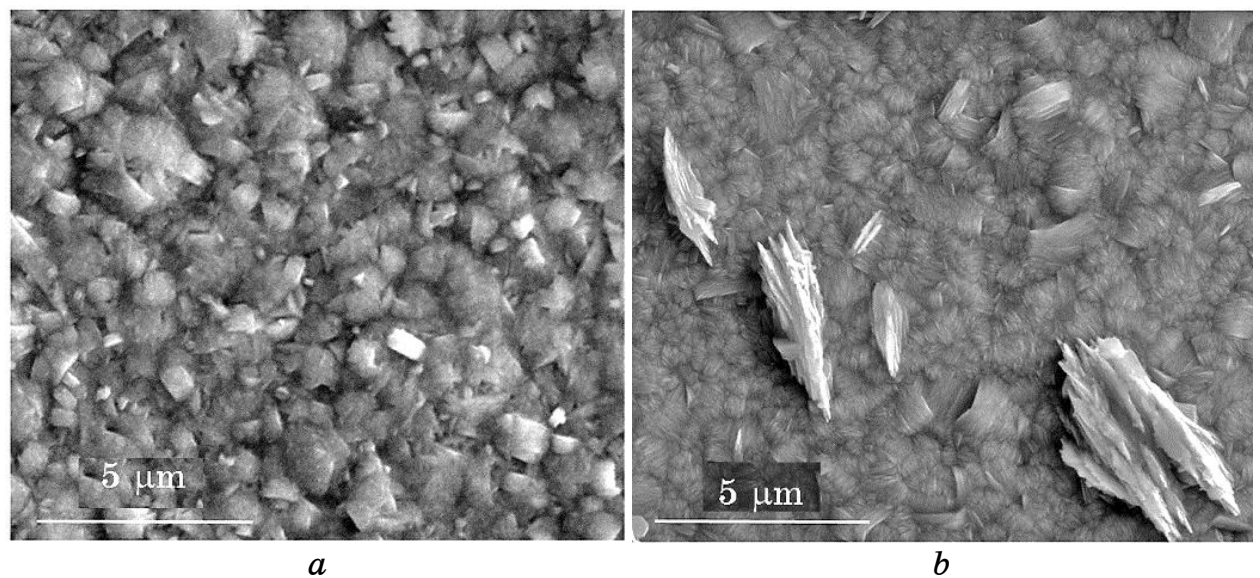

Fig. 1. SEM images of Zn-Mo coatings with $0.8(a)$ and $3.6 \%$ wt. Mo $(b)$ deposited on steel substrate. 

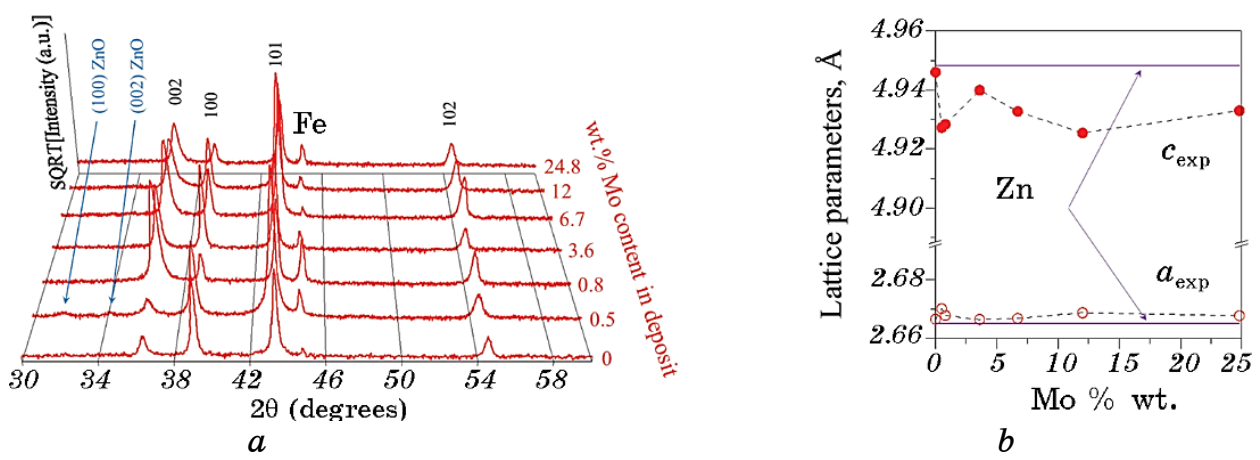

Fig. 2. Diffraction patterns of the Zn-Mo deposits (a). Dependence of the unit cell parameters' values on the content of molybdenum in deposits $(b)$.

denum in the hexagonal phase is very low-probably about $0.5-0.8 \%$ wt. (see Fig. $2, b$ ). It should be noted that the layer containing $0.5 \%$ of molybdenum has two phases-(Zn, Mo) and $\mathrm{ZnO}$. Hence, the actual content of molybdenum in the (Zn, Mo) phase crystal structure in this layer may be a bit larger than $0.5 \%$. Even better, this is shown in Fig. 3 .

As noted above, both unit cell parameters of zinc vary with the number of Mo atoms substituted in place of Zn. Thus, the magnitude of the number of Mo atoms introduced into places of $\mathrm{Zn}$ atoms in the zinc structure can be determined from the ratio of the unit cell parameters of zinc: $c / a$. As one can see in Fig. 3, all measurement points are between 0 and $0.5 \%$ wt. Mo. Hence, it is concluded that under the given conditions of the electrolysis process and the composition of the bath, the resulting layers have one crystalline phase. This phase is crystallized in the zinc structure, and the maximum Mo content in it is slight-

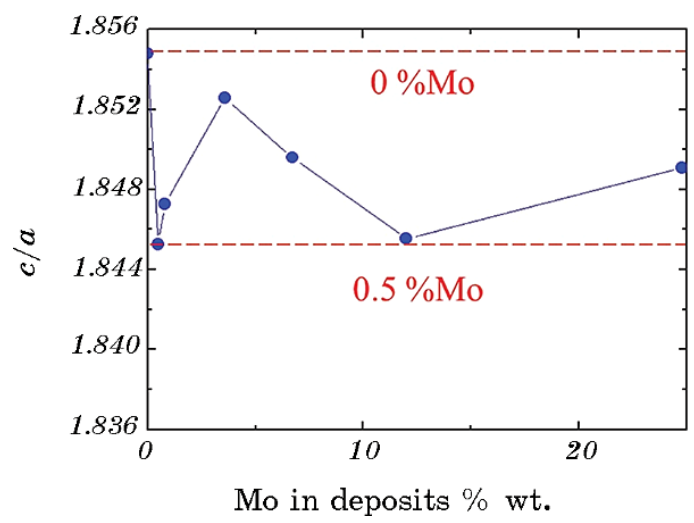

Fig. 3. The $c / a$ ratio value $v s$. \% wt. Mo content in deposits. 
ly greater than $0.5 \%$ wt.

Figure 4 shows the results of x-ray analysis of phase composition and microstructure of layers. In addition to values of lattice parameters of the identified hexagonal (Zn, Mo) phase, the approximate shape and characteristic sizes of the crystallites are also shown.

The analysis of $x$-ray diffraction data indicates that the presence of Mo causes a fragmentation of the crystallites. This is perfectly evident in Fig. 5, $a$, which shows the relationship between relative volume of
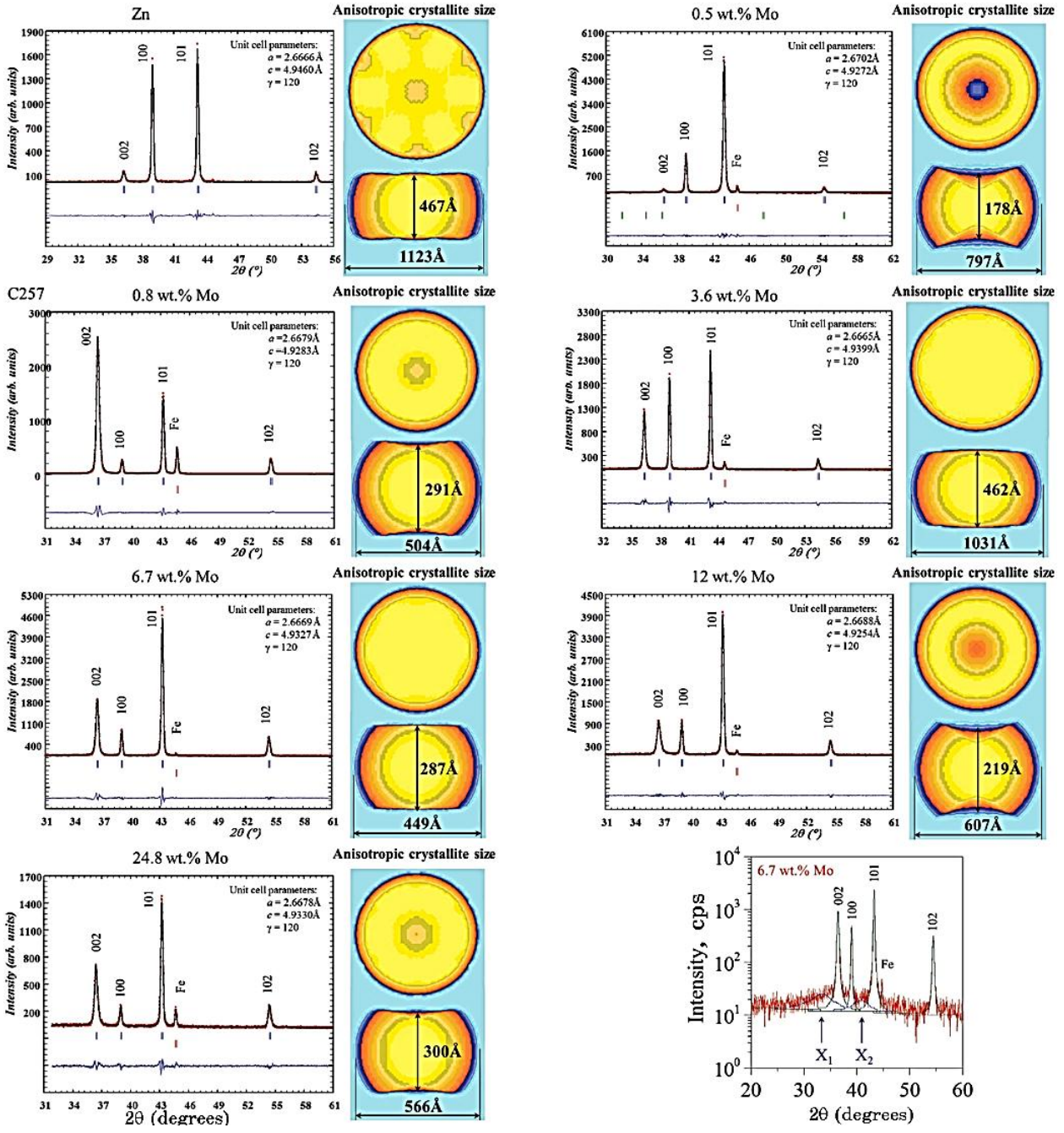

Fig. 4. The diffraction patterns of the $\mathrm{Zn}-$ Mo deposits. On the right of each diffraction pattern, the designated shape and characteristic size of the crystallites for phases crystallizing in a hexagonal system are shown. 
crystallite $V / V_{\mathrm{Zn}}\left(V\right.$-volume of the $(\mathrm{Zn}, \mathrm{Mo})$ phase crystallite, $V_{\mathrm{Zn}}-$ volume of zinc crystallite) and $c / a$ ratio. With the increase in the content of Mo atoms in the zinc structure (decrease in $c / a$ ratio), the crystallite volume initially drops sharply and then reaches an almost constant value. The shape of the crystallite is also slightly altered. Figure $5, b$ shows the dependence of the shape parameter of crystallite, $D / H$ ( $D$-crystallite diameter, $H$-crystallite height; see Fig. 4 ), on the $c / a$ ratio. As can be perfectly seen initially with the increase in the content of Mo atoms in the zinc structure, the shape of the crystallite varies from flattened oval to almost spherical, and then tends to plate. It should be noted that in the layer containing the highest number of Mo atoms in the zinc structure the presence of $\mathrm{ZnO}$ was detected.

Next, it is known that only a small amount of Mo is introduced into the crystal lattice of $(\mathrm{Zn}, \mathrm{Mo})$ phase crystallizing in a hexagonal system (as evidenced by small changes in the unit cell parameters of hexagonal phase identified-compare values of the lattice parameters in Fig. 2, b).

We estimated that a maximum of only about $0.5 \mathrm{wt}$. percent Mo is introduced into the crystal structure of hexagonal system. The rest of molybdenum atoms can remain in the amorphous phase, nanocrystalline or Zn-Mo particles (look at the characteristic for amorphous phase greatly broadened peaks $\mathrm{X}_{1}$ and $\mathrm{X}_{2}$ in Fig. 4). Nature of this indeterminate phase is currently unclear. However, already based on these results of XRD, it can be assumed that this phase was rather created by blockade of the crystallization of hexagonal phase by molybdenum atoms than by the crystallization of the equilibrium phase from the cubic or orthorhombic system $\left(\mathrm{MoZn}_{7}\right.$ or $\mathrm{MoZn}_{22}$ according to [11]). Thus, the deposition process takes place by crystallization of the hexagonal phase, and the excess of Mo atoms causes blocking the crystal structure development.

In our previous study [4], we showed that a uniform alloy composi-

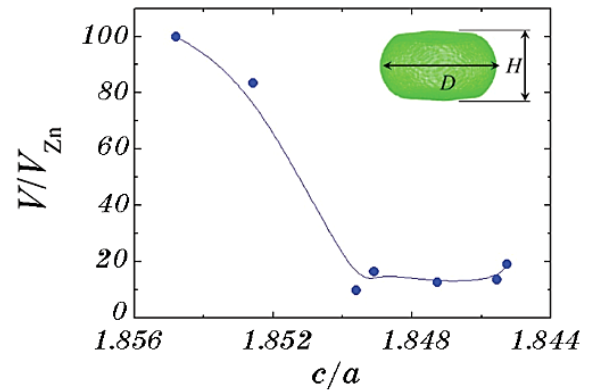

$a$

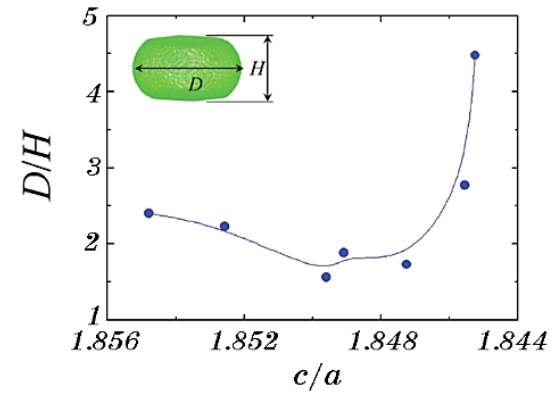

$b$

Fig. 5. Relationship between both the relative volume of crystallite $\left(V / V_{\mathrm{Zn}}\right)$ and its shape parameter $(D / H)$ and $c / a$ ratio. 
tion along its cross-section was observed. The molybdenum and zinc were very evenly distributed within the coating. The coating appears to be continuous, no cracks were observed. This observation confirms our above supposition about a microstructure of layers obtained: the layers contain a fine crystalline hexagonal phase (Zn, Mo) 'surrounded' by an amorphous phase, nanocrystalline or Zn-Mo particles. The presence of amorphous and nanocrystalline phases has been confirmed in transmission electron microscopy experiments (Fig. 6).

Figure 6 shows cross-sectional bright-field (Fig. 6, $a$ ) and dark-field (Fig. 6, $b$ ) TEM images of selected part of the $\mathrm{Zn}$-Mo coating containing $3.6 \%$ wt. Mo. In the Fig. 6 , $b$, very small crystallites (with size of several nanometres and smaller) are clearly visible on the background of amorphous phase.

Lattice parameters are basic characteristics of crystalline materials. Any variation of cell parameters can be caused by a change in the chemical composition of crystalline material and/or by a strain of its crystal lattice. Such deviations of the actual crystal lattice from a reference lattice can be determined from the geometry of high order Laue zone lines present in convergent beam electron diffraction (CBED) patterns [12]. The CBED based method offers reasonable accuracy of a very good nanoscale spatial resolution. The resolution makes this technique suitable for correlating the variation of cell parameters with elements of microstructure. This method was applied to detection of any changes in cell parameters of ( $\mathrm{Zn}, \mathrm{Mo})$ phase in the deposit containing $0.8 \%$ wt. Mo.

Figure 7, $a$ shows the mapped area in conducted research. This area covered $100 \times 100$ measuring points with the step of $20 \mathrm{~nm}$. As an example, Fig. 7, $b$ shows the diffraction patterns in the immediate vicinity of the selected point $A(50,38)$ (Fig. $7, a)$. Very complex diffraction patterns composed of overlapping diffraction patterns of neighbour-
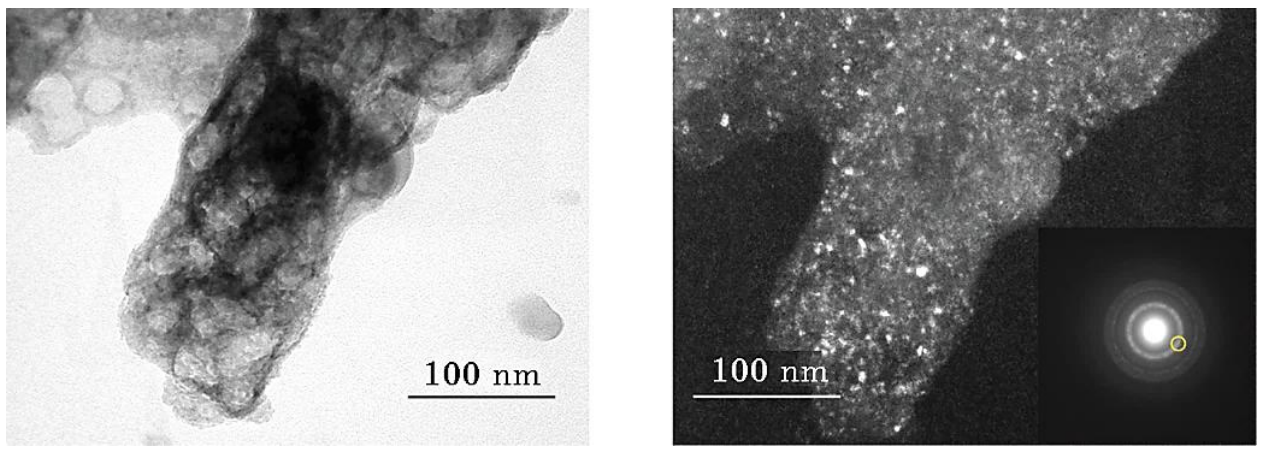

Fig. 6. Bright-field ( $a$ ) and dark-field $(b)$ TEM images showing the presence of amorphous and nanocrystalline phases in the layer containing $3.6 \%$ of molybdenum. 

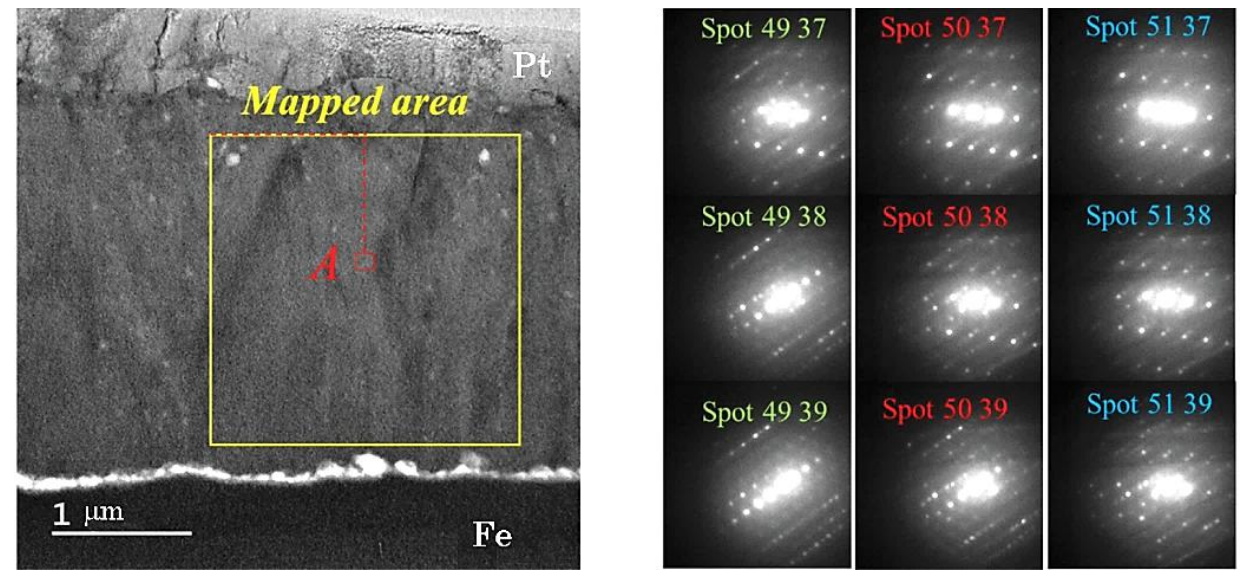

Fig. 7. Cross-section electron micrograph showing mapped area in the microstructural studies $(a)$ and electron diffraction patterns from the nearest neighbourhood of selected point $A(50,38)(b)$.

ing crystallites were obtained. The analysis of such diffraction patterns is very difficult, and the results would be affected by significant errors. For this reason, the changes in the unit cell parameters were not determined. Nevertheless, the results obtained not only confirm the fine-crystalline nature of $(\mathrm{Zn}, \mathrm{Mo})$ phase, but also indicate different orientations of the crystallites.

\section{CONCLUSIONS}

The single-phase deposits with the same type of crystal lattice (of hexagonal close packed one) were obtained by electrodeposition from sulphate-citrate baths. In the structure of this phase, the molybdenum atoms were introduced into the zinc places. Introduction of the alloying atoms into places of the $\mathrm{Zn}$ atoms causes a change of the crystal lattice unit cell parameters as well as a fragmentation of the crystallites. Based on the analysis of the x-ray diffraction patterns of Zn-Mo layers, it is estimated that a maximum of only about $0.5-0.8 \%$ wt. Mo is introduced into the crystal structure of hexagonal system, and the rest of molybdenum atoms can remain in the amorphous phase, nanocrystalline or $\mathrm{Zn}-$ Mo particles.

\section{ACKNOWLEDGEMENTS}

The authors wish to express their thanks to Prof. Adam Morawiec from the Institute of Metallurgy and Materials Science for the TEM investigations. 


\section{REFERENCES}

1. F. C. Porter, A. M. Stoneman, and R. G. Thilthorpe, Transactions of the Institute of Metal Finishing, 66: 28 (1998).

2. R. Pfiz and G. Strube, Transactions of the Institute of Metal Finishing, 74: 158 (1996).

3. R. Sard, Plating and Surface Finishing, 74: 30 (1987).

4. H. Kazimierczak, P. Ozga, Z. Swiatek, and E. Bielanska, J. Alloys Compd., 578: 82 (2013).

5. J. Rodriguez-Carvajal, Physica B: Condensed Matter, 192: 55 (1993), http://www.ill.eu/sites/fullprof/php/downloads.html

6. A. LeBail, H. Duroy, and J. L. Fourquet, Materials Research Bulletin, 23: 447 (1988).

7. J. Rodriguez-Carvajal, J. Phys. B, 192: 55 (1993); Recent Developments of the Program FULLPROF, Commission on Powder Diffraction (IUCr), Newsletter, No. 26: 12 (2001).

8. A .Boultif and D. Louer, J.Appl. Crystallogr., 37: 724 (2004).

9. P. Thompson, D. E. Cox, and J. B. Hastings, J. Appl. Crystallogr, 20: 79 (1987).

10. Defect and Microstructure Analysis by Diffraction (Eds. R. L. Snyder, J. Fiala, and H. J. Bunge) (Chester, Oxford: IUCr/Oxford University Press: 1999), p. 41.

11. T. B. Massalski, P. R. Subramanian, H. Okamoto, and L. Kacprzak, Binary Alloy Phase Diagrams (Materials Park, OH: ASM International: 1990).

12. A. Morawiec, Ultramicroscopy, 107: 390 (2007). 